Asian Journal of Medical and Biological Research ISSN 2411-4472 (Print) 2412-5571 (Online) https://www.ebupress.com/journal/ajmbr/

\title{
Article
}

\section{Buffalo production in small scale and commercial farms in Bangladesh}

R. C. Chanda ${ }^{1 *}$, M. Moniruzzaman ${ }^{1 *}$, Md. Hasanur Alam ${ }^{1}$, Asma Khatun ${ }^{1}$, Md. Nuronnabi Islam¹, Md. Enayet Kabir ${ }^{2}$, Md. Ahidul Islam ${ }^{3}$ and Md. Ruhul Amin ${ }^{1}$

${ }^{1}$ Department of Animal Science, Bangladesh Agricultural University, Mymensingh-2202, Bangladesh

${ }^{2}$ Department of Animal Production and Management, Sher-e-Bangla Agricultural University, Dhaka-1207, Bangladesh

${ }^{3}$ Department of Animal Science, Patuakhali Science and Technology University, Dumki, Patuakhali, Bangladesh

*R. C. Chanda and M. Moniruzzaman contributed equally to this work

*Corresponding author: Professor Dr. Mohammad Moniruzzaman, Department of Animal Science, Bangladesh Agricultural University, Mymensingh-2202, Bangladesh. Phone: 880-91-67401-6/ Ext-2620; Fax: 880-9161510; E-mail: monir.as@bau.edu.bd

Received: 02 November 2021/Accepted: 28 November 2021/ Published: 30 December 2021

Copyright (C) 2021 R. C. Chanda et al. This is an open access article distributed under the Creative Commons Attribution 4.0 International License (https://creativecommons.org/licenses/by/4.0/), which permits unrestricted use, distribution, and reproduction in any medium, provided the original work is properly cited.

\begin{abstract}
The present study was aimed to compare the production status and management practices of crossbred buffaloes between small scale and commercial farms in Bangladesh. The data were collected through personal interview from the individual respondent. The study revealed that duration of buffalo rearing was mostly practiced for more than two years. Various types of feed ingredients including rice straw, wheat straw, green grass, concentrate feed, cultivated fodder, tree leaves and unconventional feed resources were used for feeding buffaloes. In small scale, $83.34 \%$ farmers fed their buffalo in a group and $75 \%$ buffaloes reared under semi-intensive system while all buffaloes practiced individual feeding and reared under intensive system in commercial farms. The daily milk production, lactation length and yield of dam and birth weight of calves significantly $(\mathrm{p}<0.05)$ increased in commercial farm than small scale. However, the weaning age and weight was significantly $(\mathrm{p}<0.05)$ higher in village buffaloes than commercial farms. Similarly, age at $1^{\text {st }}$ heat, $1^{\text {st }}$ calving, services per conception and postpartum heat showed significantly $(\mathrm{p}<0.05)$ higher values in village than commercial farms. The major diseases of buffaloes in those areas were foot and mouth disease, black quarter, hemorrhagic septicemia, mastitis and anthrax. A proportion of $88.3 \%$ village farmers performed vaccination, in contrast, all buffaloes were vaccinated in commercial farms. The cost-return analysis discovered that rearing of buffalo in commercial farms was more profitable than rearing in small scale. Finally, the results revealed that productive and reproductive performances of buffaloes were better in commercial farms than small scale condition. Buffalo rearing is more profitable in commercial farms than small scale farming.
\end{abstract}

Keywords: buffalo; management; production; small scale; commercial farm

\section{Introduction}

The buffalo (Bubalus bubalis) is a multipurpose livestock species that helps the livelihood of people by providing high quality milk and meat, dung as fuel and organic fertilizer, mechanical or draft power and hides and skins as raw material for industry (Irshad et al., 2011). They are better converters of poor quality fibrous 
feeds into milk and meat, with better degradation of both crude protein and non-protein dry matter than cattle (Terramoccia et al., 2000). They have a better digestive ability than cattle to utilize poor quality roughages (Hussain and Cheeke 1996; Bartocci et al., 1997; Agarwal et al., 2008). Use of appropriate information by buffalo owners will help them to improve knowledge enabling them to obtain more output from their buffaloes.

The management practices applied by buffalo raisers usually depends on the type of production in which they are involved. At the village level, production is usually based on a small herd of mixed ages and sexes generally for draught and breeding purposes. In a semi-intensive production system, buffaloes are kept mainly for specific purposes, i.e., either for draught or for milk production. The farmers raise buffaloes mostly in free grazing system of feeding but stall feeding is often practised in Bangladesh (Sarker et al., 2013). Several reports have been published regarding management practices of buffaloes (Faruque and Amin, 1995; Sarkar et al., 2013; Amin et al., 2015; Hasan et al., 2016; Uddin et al., 2016; Kabir et al., 2020; Haque et al., 2020) in various regions of Bangladesh. The buffalo rearing in farm condition of Bangladesh is not widely available, though some buffalo of indigenous, exotic and their crosses are being maintained in small number at some institutional farms (i.e., Bangladesh Agricultural University Dairy Farm at Mymensingh, Bangladesh Livestock Research Institute, Savar, Dhaka and Buffalo Breeding and Development Farm at Bagerhat) and some commercial farms (i.e., American Dairy Limited, Gazipur and Lal Teer Ltd., Valuka, Mymensingh). However, productivity of buffaloes mainly depend on genetic improvement, good ration, good management and also environment (Saadullah, 2012).

Production and reproduction are one of the most important considerations to determine the profitability of buffalo production. Productive and reproductive performances of buffaloes should be determined on the basis of these parameters. The productivity of indigenous buffaloes in term of milk production is low. Their reproductive efficiency is low and 2 calves in 3 years are common (Faruque et al., 1990; Faruque, 1994; Faruque and Amin, 1994; Faruque and Amin, 1995). Characterization and evaluation of indigenous buffalo in some places have been done by Amano et al. (1987); Faruque and Amin (1995); Hasnath (1985) and Hussain (1990). The characterization and evaluation of exotic improved buffaloes (Nili-Ravi and Murrah) and their crossbred progenies, observed in some localized area of the country as well as in some commercial farms which generally produce more milk, that may contribute better to fulfill the demand.

Though the buffalo is an important part of livestock in Bangladesh, there is a few documented research studies so far that investigated the production status of buffaloes and their management practices in some selected areas of Bangladesh. A limited information is available on production status of buffaloes and their management practices at the farm level. This study was aimed to know the management practices along with the productive and reproductive performances of native buffaloes and also cost-benefit analysis of rearing buffaloes in the villages and commercial farms.

\section{Materials and Methods}

\subsection{Study area}

The study was conducted at five villages named Kanihari, Jilky, Kustia, Mandatia and Sultanpur of Trishal Upazila and two commercial farms, named, Lal Teer Ltd. in Valuka Upazilla of Mymensingh district and American Dairy Limited in Sripur Upazila of Gazipur district of Bangladesh.

\subsection{Selection of respondent}

Data were collected from farmers who reared at least two buffaloes. A number of 60 respondents from five villages were chosen for collection of data. Owners of the buffaloes were selected randomly from five villages of the Upazilla of Trishal for collection of information. The farmers who were interested to provide information willingly were interviewed.

\subsection{Preparation of interview schedule}

The interview schedule was carefully prepared based on the objectives of the study. A draft schedule was developed before preparing the final schedule. The draft schedule was then pre-tested with selected farmers in the study area and then it was rearranged and modified as required. The schedule was developed in a simple manner to avoid confusion and to get accurate answer. Then it was finalized according to the experiences of preliminary field survey.

\subsection{Data collection}

Data were collected through personal interview from the individual respondent present in their own house. An introductory visit was made to the study area when the objects of the study were explained to most of the 
respondents. This helped to have a friendly orientation of the respondents. Brief information regarding the nature and purpose of the study was made to the respondents before actual interview. Questions were asked systemically and explain whenever it was felt necessary. The information supplied by the respondents was recorded directly on the interview schedule. The respondents were interviewed at their own house. Data was collected during October, 2017 to March, 2018. After completion of field survey all the interview schedules were set for its data tabulation for coding and reduction. All the individual variables of the interview schedules were transferred to master sheet to facilitate tabulation.

\subsection{Measurement of variables}

The duration of buffalo rearing, breeding technique, feeding method, housing facility, rearing system, productive and reproductive performance, daily routine activities of farmers for buffalo rearing, annual cost of production per buffalo, annual income per buffalo were studied.

\subsection{Statistical analysis}

Qualitative data were converted into quantitative by means of suitable scoring technique wherever applicable. The data generated from this study were entered in Microsoft Excel worksheet, organized and processed for further analysis. All data were subjected to one-way ANOVA, Mean \pm SD and the significance difference between means was determined using Tukey's HSD test. All data were analyzed in "SAS version 9.1.3" for Windows Service Pack 4, 2004 SAS Institute, Cary NC USA for Windows. Differences at $\mathrm{p}<0.05$ were considered statistically significant.

\section{Results and Discussion}

\subsection{Duration of rearing a buffalo}

Duration of buffalo rearing by the buffalo farmers is presented in Table 1. A proportion of $38.3 \%$ farmers kept buffaloes for more than 2 years and $33.3 \%$ farmers kept for 2 years in small scale. In Moulvibazar district of Bangladesh, $40 \%$ farmers kept buffaloes for 2 years (Sumaiya, 2015) which is in good agreement with our findings. On the other hand, buffaloes were reared for more than 2 years in commercial farm.

\subsection{Feeds and feeding}

The types of feed offered to buffaloes in the experimental areas are presented in Table 2. Various types of feed ingredients including rice straw, wheat straw, green grass, concentrate feed, tree leaves and unconventional feed resources were offered to buffaloes in the study area. In the villages, $58.4 \%$ farmers offered rice straw supplemented with some concentrates $(16.7 \%)$ such as wheat bran, rice bran, mastered oil cake to their buffaloes. A number of 3.4\% farmers provided their buffaloes with unconventional feed resources such as water hyacinth, sugarcane tops, Helancha, Belencha, Buchai lata, kitchen wastes etc. Some exclusive feed items specially tree leaves and roadside green grass were given by the farmers (about 8.3\%) to their animals because roadside green grasses and tree leaves are available in that area. A few farmers (13.4\%) cultivated fodders for buffaloes at the village. In Trishal areas, due to the scarcity of green grass and grazing land, buffalo farmers migrated their buffaloes to Sylhet region for the month of mid- January to May (4-5 months). In contrast, 53.4\% buffaloes offered cultivated fodders such as Napier, German, Para, and Maize in commercial farm. About 26.7\% and $20 \%$ buffaloes offered rice straw and concentrates, respectively. Tree leaves and unconventional feeds were not offered to the buffaloes in the commercial farm. The feeding method of buffaloes are presented in Table 2 . In the experimental areas $83.4 \%$ farmers fed their buffalo in groups and rests (16.6\%) practiced individual feeding. This observation supports the result of (Siddiki et al., 2015). They reported that 89, 90 and 85\% farmers fed their buffalo in groups in Subornochar, Bagha and Lalpur Upazila, respectively. In commercial farms, buffaloes were fed individually.

\subsection{Rearing systems of buffalo}

The rearing systems of buffaloes are presented in Table 3. In the experimental areas, $75 \%$ reared their buffalo in semi-intensive system allowing them to graze for a period of $6-8 \mathrm{~h}$ in a day while $25 \%$ farmers allow their buffaloes for a longer period of grazing for 10-12 h in a day. Amin et al. (2015) reported that $85 \%$ of the buffalo farmers reared buffalo in semi-intensive system followed average grazing period of 6-8 $\mathrm{h}$ in a day. In commercial farm, all buffalo were reared in intensive system. The housing facilities for buffaloes is also presented in Table 3. In the experimental areas, $83.3 \%$ farmers did not provide housing for their buffaloes. The unavailability of housing of several village areas of Bangladesh were 84\% (Amin et al., 2015). In contrast, housing facilities for all buffaloes were ensured in commercial farm. 


\subsection{Breeding practices}

The breeding technique for buffaloes is presented in Table 3. In small scale, $91.6 \%$ farmers practiced natural services due to availability of buffalo bulls in their locality and $8.4 \%$ farmers practiced artificial insemination (AI) to breed their buffalo. Whereas, all buffaloes were inseminated artificially in the commercial farms.

\subsection{Daily activities in buffalo farm}

A daily routine activity in buffalo rearing in the study area is presented in Table 4. At 5.0-6.0 am dry grass and water were offered to village buffaloes although in commercial farm, sheds were being cleaned and fresh water was supplied to buffaloes. After that at 6.00-6.30 am the village buffalo bulls were taken to the land for cultivation, but in commercial farm, green fodder was given to buffalo by the farmers. At 7.00-7.30 am the buffalo calves were taken to their mother for suckling both in the small scale and commercial farm. Generally, buffaloes were milked between 7.00-9.00 am. Village buffaloes were taken to the nearby swampland where buffaloes were kept until $5.00 \mathrm{pm}$, meanwhile in commercial farms, buffaloes were kept always in the shed. At $5.00 \mathrm{pm}$ in the small scale the calves were taken to their mother for suckling while labour left the shed in the commercial farm. Between 5.30-6.00 pm the village buffaloes were brought back to the farmer's home and housed there meanwhile in the commercial farm, buffaloes were housed in the shed.

\subsection{Productive performance of buffalo}

The productive performances of crossbred buffaloes in the study area are presented in Table 5. Milk production, lactation length and yield of dam and birth weight of calves were significantly higher in commercial farm than small scale. Whereas weaning age and weight were significantly higher in small scale than commercial farms. The average daily milk production of buffaloes in small scale and commercial farm was found $3.8 \pm 0.2 \mathrm{~L} / \mathrm{d}$ and $7.1 \pm 0.2 \mathrm{~L} / \mathrm{d}$, respectively. Similar type of findings were reported by Siddiquee et al. (2010) and Amin et al. (2015). Present findings differ with the finding of Khan et al. (2014) who reported that Azikheli buffalo of Pakistan produced daily 7.19 liters of milk. Siddiquee et al. (2010) reported that the average lactation yield was $995.5 \pm 120.2$ liters in Companigonj which is similar with the present findings. The lactation length (230.6 days) in our present findings agreed with the findings of Siddiquee et al. (2010) who reported that the lactation length of buffalo ranged from 258.67 to 289.82 days. The average birth weight of crossbred buffalo calves were $30.1 \pm$ $0.3 \mathrm{~kg}$ and $36.1 \pm 1.1 \mathrm{~kg}$ in village and farm condition, respectively which was similar with the findings of Amin et al. (2014). The average weaning age of crossbred buffalo calves in Subornochar Upazila of Bangladesh was 14 months (Amin et al., 2014). However our findings suggest that the average weaning age usually much lower in both village and commercial farm condition.

\subsection{Reproductive performance of buffalo}

Various traits related to reproductive performances of buffaloes in the study area is presented in Table 6 . The average age at first heat of crossbred buffaloes in small scale and commercial farm was found $3.04 \pm 0.04$ years and $1.96 \pm 0.19$ years, respectively and varied significantly $(\mathrm{p}<0.05)$ between the two areas. Similarly, age at $1^{\text {st }}$ calving and number of services per conception were significantly higher in village buffaloes than commercial farms. The age at puberty of buffaloes of Companigong areas of Bangladesh usually 4.6 years (Siddiquee et al., 2010). The average age at $1^{\text {st }}$ calving of buffaloes in the present finding (4 years) agreed with the findings of Siddiquee et al. (2010), Amin et al. (2015) and Siddiki et al. (2015). They found that the age at $1^{\text {st }}$ calving of buffalo varied from 36-59 months. The average number of service per conception of coastal region buffaloes of Subornochar Upozila was 3.1 times reported by Amin et al. (2015) supported the present finding (2.46 times), but disagreed with the findings of Khan et al. (2014). They reported that the number of service per conception of Azikheli buffaloes in Pakistan and Bangladeshi native buffaloes were 1.5 and 1.4 times, respectively. The postpartum heat period (PPHP) varied from 30 to 171 days reported by Faruque et al. (1990) and Amin et al. (2015). This finding is similar with the reported PPHP in the present study. The average calving interval of buffaloes differ with the findings of Khan et al. (2014). They reported that the calving interval of buffaloes ranged from 483 to 750 days.

\subsection{Health management of buffalo}

The health management systems of study area are presented in Table 7. In the experimental areas, five major diseases of buffalo were Anthrax, Foot and mouth disease (FMD), Mastitis, Hemorrhagic septicemia (HS), and Black quarter (BQ). A number of farmers $(58.3 \%)$ mentioned the occurrence of FMD. More than $25 \%$ farmers claimed the prevalence of $\mathrm{BQ}$. Almost $8.3 \%, 5 \%$ and $3.3 \%$ buffalo farmers claimed about Anthrax, HS and Mastitis respectively. This indicated that the buffaloes of village area are more susceptible to Foot and mouth 
disease (FMD), because village farmer had a little knowledge about the causes of FMD. Gupta et al. (2014) reported the prevalence of infectious diseases like FMD, HS, BQ in buffaloes were the main problem. The occurrence of FMD in Bagerhat district was 57\% which is in good agreement with the findings (58.3\%) reported by Sarkar et al. (2013). In contrast, there were a reduced rate of the susceptibility of those diseases in commercial farm.

It was found that $88.3 \%$ village buffaloes were vaccinated against infectious disease which is related with the result of Sumaiya (2015). She reported that $89 \%$ buffalo farmers vaccinated their buffaloes against infectious diseases in Kulaura Upazilla of Moulvibazar district. In the study areas, a proportion of $90 \%$ farmers collected vaccines from the local pharmacy and $10 \%$ collected vaccines from local office of Livestock Department. In contrast, all buffaloes vaccinated with imported vaccines in commercial farms. A proportion of $73.4 \%$ buffalo farmers took veterinary service. Sumaiya (2015) reported that $77 \%$ buffalo farmers took veterinary service for their buffaloes. In commercial farms, all buffaloes got veterinary care. In small scale, $83.4 \%$ buffalo farmers dewormed their buffaloes and $16.6 \%$ used to go to Upazilla Livestock Office in case of disease occurrence which agreed with the result of Sarkar et al. (2013). They reported that 81.7\% farmers performed deworming and $18.3 \%$ used to go to Upazilla Livestock Office for medicate their buffaloes in Bagerhat district of Bangladesh. In contrast, all buffaloes were dewormed regularly once in every three months in commercial farm.

\subsection{Cost of buffalo production}

The cost of feeding, breeding, housing equipment and medication is presented in Table 8 . To analyze the costreturn, it is necessary to describe the feed cost, breeding cost and cost of housing and equipment for buffalo rearing. The average cost of housing and equipment (per year) was lower than the average feed cost in both small scale and commercial farm. In small scale, farmers generally bred their buffalo from the neighbor's buffalo bull and they hardly performed artificial insemination to their buffaloes. For this reason, the breeding cost in village was lower than the commercial farm. Medication cost includes the price of medicine and vaccine. The village farmer mostly dependent on local veterinary pharmacy for medicine which was not so far away from their house. They did not get enough facilities from the livestock office. Some NGO's of those area performed several programs on the vaccination, deworming and treatment. It was much helpful to the buffalo farmers of this region. In commercial farm, the farm owner imported medicine and vaccine from India for the betterment of herd. Gross rearing cost of per buffalo per year in small scale and commercial farm was 39860.8 \pm 1384.7 and $136443.6 \pm 411.2$ BDT respectively. However, cost of feed was the maximum among the rearing cost. The second highest cost was housing and it equipment.

\subsection{Profitability of buffalo farming}

The income per buffalo per year is presented in Table 9. The gross income per year per buffalo in small scale and commercial farm was $51996.1 \pm 315.7$ BDT and 182178.9 \pm 370 BDT, respectively. The net income per buffalo per year in small scale and commercial farm were $12135.3 \pm 1069$ and $45735.3 \pm 111.2$ BDT, respectively. The net income from one buffalo per year was 15630 BDT, reported by Sarkar et al. (2013) which is in good agreement with the present study. The findings of the present study also agreed with the findings of Kailash et al. (2009), who reported that higher net income was found per buffalo was Rs. 15392.00 per year.

Table 1. Rearing duration of buffalo.

\begin{tabular}{lllll}
\hline Duration & \multicolumn{2}{c}{ Small scale } & \multicolumn{2}{c}{ Commercial farm } \\
\cline { 2 - 5 } & Frequency & Percent & Frequency & Percent \\
\hline 6 months & 4 & 6.7 & 0 & 0 \\
1 year & 13 & 21.7 & 0 & 0 \\
2 year & 20 & 33.3 & & 0 \\
More than 2 years & 23 & 38.3 & 75 & 100 \\
\hline Total & 60 & 100 & 75 & 100 \\
\hline
\end{tabular}


Table 2. Feeding management of buffalo.

\begin{tabular}{lllll}
\hline \multirow{2}{*}{ Type of feeds } & \multicolumn{2}{c}{ Small scale } & \multicolumn{2}{c}{ Commercial farm } \\
\cline { 2 - 5 } & Frequency & Percent & Frequency & Percent \\
\hline Rice straw & 35 & 58.4 & 20 & 26.7 \\
Concentrate & 10 & 16.7 & 15 & 20 \\
$\begin{array}{l}\text { Cultivated } \\
\text { fodders }\end{array}$ & 8 & 13.4 & 40 & 53.4 \\
$\begin{array}{l}\text { Roadside grass } \\
\text { and tree leaves }\end{array}$ & 5 & & 0 & 0 \\
Unconventional feed & 2 & & & 0 \\
\hline Feeding System & & 3.4 & 0 & 0 \\
\hline Group feeding & 50 & & & 100 \\
Individual feeding & 10 & 83.4 & 0 & \\
\hline
\end{tabular}

Table 3. Management and breeding practices of buffalo.

\begin{tabular}{lllll}
\hline Rearing system & \multicolumn{2}{c}{ Small scale } & \multicolumn{2}{c}{ Commercial farm } \\
\cline { 2 - 5 } & Frequency & Percent & Frequency & Percent \\
\hline Intensive & 0 & 0 & 75 & 100 \\
Semi-intensive & 45 & 75 & 0 & 0 \\
Extensive & 15 & 25 & 0 & 0 \\
\hline Housing facilities & & & 75 & 100 \\
\hline Available & 10 & 16.6 & 0 & 0 \\
Unavailable & 50 & 83.3 & & 100 \\
\hline Breeding technique & & & 75 & 0 \\
\hline AI & 5 & 8.4 & 0 & \\
Natural services & 55 & 91.6 & & \\
\hline
\end{tabular}

Table 4. Daily activities in buffalo farms.

\begin{tabular}{|c|c|c|}
\hline \multirow[t]{2}{*}{ Time } & Small scale & \multirow{2}{*}{$\frac{\text { Commercial farm }}{\text { Activities }}$} \\
\hline & Activities & \\
\hline $5.00-6.00 \mathrm{am}$ & $\begin{array}{l}\text { Buffaloes were provided by dry grass or straw and } \\
\text { drinking water }\end{array}$ & $\begin{array}{l}\text { Cleaning the shed and give fresh water } \\
\text { in the manger }\end{array}$ \\
\hline $6.00-6.30 \mathrm{am}$ & Buffaloes were bring to the field for cultivation purpose & Gave green fodder to buffalo \\
\hline $7.00-7.15 \mathrm{am}$ & $\begin{array}{l}\text { In case of milking buffaloes the calves were bring to their } \\
\text { mother for suckling }\end{array}$ & Preparation for milking \\
\hline $7.15-9.00 \mathrm{am}$ & Buffaloes were milked under the open sky. & Buffaloes were milked in shed. \\
\hline $6.30-11.00 \mathrm{am}$ & Male buffaloes were used to plough the land. & Collecting semen from male buffaloes \\
\hline $11.00-5.00 \mathrm{pm}$ & $\begin{array}{l}\text { Buffaloes were taken to the swamp land for grazing as well } \\
\text { as wallowing }\end{array}$ & Buffaloes were in stall. \\
\hline $5.00-5.30 \mathrm{pm}$ & Calves were kept in the yard and supplied soft green grass. & Calves were separated in calf barn. \\
\hline $5.00-5.30 \mathrm{pm}$ & $\begin{array}{l}\text { Buffaloes were returned to the home and offered feed \& } \\
\text { water and were milked }\end{array}$ & Security guard entered the shed \\
\hline $6.00 \mathrm{pm}$ & Buffaloes were sheltered under the trees of the farmer. & Buffaloes were sheltered in shed \\
\hline
\end{tabular}

Table 5. Productive performance of buffalo.

\begin{tabular}{lllllll}
\hline Category & $\begin{array}{l}\text { Milk } \\
\text { Production } \\
(\mathbf{L} / \mathbf{d})\end{array}$ & $\begin{array}{l}\text { Lactation } \\
\text { Length } \\
\text { (days) }\end{array}$ & $\begin{array}{l}\text { Lactation Yield } \\
\text { (L/lactation) }\end{array}$ & $\begin{array}{l}\text { Birth } \\
\text { weight } \\
(\mathbf{k g})\end{array}$ & $\begin{array}{l}\text { Weaning age } \\
\text { (month) }\end{array}$ & $\begin{array}{l}\text { Weaning } \\
\text { weight. (kg) }\end{array}$ \\
\hline Small scale & $3.8^{\mathrm{b}} \pm 0.2$ & $230.1^{\mathrm{b}} \pm 6.1$ & $1081.3^{\mathrm{b}} \pm 71.7$ & $30.1^{\mathrm{b}} \pm 0.3$ & $8.0^{\mathrm{a}} \pm 0.1$ & $107.9^{\mathrm{a}} \pm 2.2$ \\
Commercial & $7.1^{\mathrm{a}} \pm 0.2$ & $301.9^{\mathrm{a}} \pm 2.3$ & $2177.2^{\mathrm{a}} \pm 58.7$ & $36.1^{\mathrm{a}} \pm 1.2$ & $5.1^{\mathrm{b}} \pm 0.1$ & $75.1^{\mathrm{b}} \pm 2.0$ \\
Farm & & & & & & \\
\hline
\end{tabular}

${ }^{\mathrm{a}, \mathrm{b}}$ values with different superscripts at the same column differ significantly $(\mathrm{p}<0.05)$ 
Table 6. Reproductive performances of buffalo.

\begin{tabular}{lcllll}
\hline Category & $\begin{array}{l}\text { Age at } \mathbf{1}^{\text {st }} \\
\text { heat }(\mathbf{y r s})\end{array}$ & $\begin{array}{l}\text { Age at }^{\text {st }} \\
\text { calving (yrs) }^{\text {st }}\end{array}$ & $\begin{array}{l}\text { No of services } \\
\text { / conception }\end{array}$ & $\begin{array}{l}\text { Postpartum } \\
\text { heat (days) }\end{array}$ & $\begin{array}{l}\text { Calving interval } \\
\text { (yrs) }\end{array}$ \\
\hline Small scale & $3.0^{\mathrm{a}} \pm 0.1$ & $4.0^{\mathrm{a}} \pm 0.1$ & $2.4^{\mathrm{a}} \pm 0.1$ & $117.9^{\mathrm{a}} \pm 2.9$ & $1.3 \pm 0.1$ \\
Commercial Farm & $1.9^{\mathrm{b}} \pm 0.1$ & $3.1^{\mathrm{b}} \pm 0.1$ & $1.4^{\mathrm{b}} \pm 0.1$ & $113.0^{\mathrm{b}} \pm 3.3$ & $1.2 \pm 0.1$ \\
\hline
\end{tabular}

${ }^{\mathrm{a}, \mathrm{b}}$ values with different superscripts at the same column differ significantly $(\mathrm{p}<0.05)$

Table 7. Health management of buffalo.

\begin{tabular}{|c|c|c|c|c|}
\hline \multirow{2}{*}{ Name of disease } & \multicolumn{2}{|c|}{ Small scale } & \multicolumn{2}{|c|}{ Commercial farm } \\
\hline & Frequency & Percent & Frequency & Percent \\
\hline Anthrax & 5 & 8.3 & 0 & 0 \\
\hline $\begin{array}{l}\text { Foot and mouth } \\
\text { disease(FMD) }\end{array}$ & 35 & 58.3 & 10 & 40 \\
\hline Mastitis & 2 & 3.3 & 5 & 20 \\
\hline $\begin{array}{l}\text { Hemorrhagic } \\
\text { septicemia (HS) }\end{array}$ & 3 & 5 & 5 & 20 \\
\hline Black quarter $(\mathrm{BQ})$ & 15 & 25 & 5 & 20 \\
\hline \multicolumn{5}{|l|}{ Vaccination } \\
\hline Yes & 53 & 88.3 & 75 & 100 \\
\hline No & 7 & 11.7 & 0 & 0 \\
\hline \multicolumn{5}{|l|}{ Source of vaccine } \\
\hline Local pharmacy & 54 & 90 & 0 & 0 \\
\hline Livestock office & 6 & 10 & 0 & 0 \\
\hline Imported & 00 & 00 & 75 & 100 \\
\hline \multicolumn{5}{|l|}{ Medication } \\
\hline Yes & 44 & 73.4 & 75 & 100 \\
\hline No & 16 & 26.7 & 0 & 0 \\
\hline \multicolumn{5}{|l|}{ Types of Medication } \\
\hline Deworming & 50 & 83.4 & 75 & 100 \\
\hline $\begin{array}{l}\text { Receiving service from } \\
\text { livestock office }\end{array}$ & 10 & 16.6 & 0 & 0 \\
\hline
\end{tabular}

Table 8. Production cost per buffalo per year (BDT).

\begin{tabular}{lll}
\hline Category & Small scale & Commercial farm \\
\hline Feed cost & $36625 \pm 1348.2$ & $88686.2 \pm 241.5$ \\
Breeding cost & $214.8 \pm 4.4$ & $881.2 \pm 18.9$ \\
Housing cost & $2501 \pm 18.7$ & $5360 \pm 134.9$ \\
Medication cost & $520 \pm 13.4$ & $1516.2 \pm 16.4$ \\
\hline Total cost & $39,860.8 \pm 1384.7$ & $13,6443.6 \pm 411.2$ \\
\hline
\end{tabular}

Table 9. Income from a buffalo cow per year (BDT).

\begin{tabular}{lll}
\hline Category & Small scale & Commercial farm \\
\hline Milk & $45346.2 \pm 119.5$ & $179860.2 \pm 343.1$ \\
Cow dung & $1271.2 \pm 13.9$ & $2318.7 \pm 26.9$ \\
Drought/others & $5378.7 \pm 182.3$ & $0 \pm 0$ \\
Gross Income & $51996.1 \pm 315.7$ & $182178.9 \pm 370$ \\
Gross rearing Cost & $39860.8 \pm 1384.7$ & $136443.6 \pm 411.2$ \\
Gross net Income & $12135.3 \pm 1069$ & $45735.3 \pm 111.2$ \\
\hline
\end{tabular}

\section{Conclusions}

The results revealed that productive and reproductive performances of buffaloes were higher in commercial farms than the small scale. Buffalo rearing is more profitable in commercial farms than in small scale. 
Conflict of interest

None to declare.

\section{Authors' contribution}

R.C. Chanda and M. Moniruzzaman designed the study. R.C. Chanda collected data. M. Moniruzzaman, Md. Nuronnobi Islam and Md. Ahidul Islam did interpretation of data, and drafting the manuscript. M. Moniruzzaman, Md. Ruhul Amin and Md. Enayet Kabir guided and directed in different steps of the study. Md. Hasanur Alam and A. Khatun did statistical procedure for this research. All authors have read and approved the final manuscript.

\section{References}

Agarwal N, DN Kamra, PN Chatterjee, R Kumar and LC Chaudhary, 2008. In vitro methanogenesis, microbial profile and fermentation of green forages with buffalo rumen liquor as influenced by 2bromoethanesulphonic acid. Asian-Austral. J. Anim. Sci., 21: 818-823.

Amano T, T Namikawa, J Okada, MA Hasnath, MO Faruque and MA Majid, 1987. Karyotypes and blood protein ploymorphsms of native water buffaloes in Bangladesh. In Okada. I., (Edi), Genetic studies on breed differentiation of native domestic animals in Bangladesh. Part II. Hiroshima University, pp. 117-128.

Amin MR, MA Siddiki, AKMA Kabir, MO Faruque and ZH Khandaker, 2015. Status of buffalo farmer and buffaloes at Subornochar upozila of Noakhali District. Progress. Agri., 26: 71-78.

Bartocci S, A Amici, M Verna, S Terramoccia and F Martillotti, 1997. Solid and fluid passage rate in buffalo, cattle and sheep fed diets with different forage to concentrate ratios. Live. Prod. Sci., 52: 201-208.

Faruque MO, 1994. The indigenous buffalo in the Mymensingh district of Bangladesh. Buffalo J., 10: 91-100.

Faruque MO and MR Amin, 1994. Indigenous buffaloes in the coastal area of Bangladesh, part-1. Distribution pattern and phenotypes. Bang. J. Train. Dev., 7: 83-85.

Faruque MO and MR Amin, 1995. Indigenous buffaloes in the coastal area of Bangladesh, part-II. Productivity of indigenous buffaloes in the south western coastal area. Bang. J. Train. Dev., 8: 138-140.

Gupta JJ, KM Singh, BP Bhat and A Dey, 2014. A diagnostic study on livestock production syatem in Eastern Region of India. Indian Journal of Animal Science, 49: 101-110.

Haque MS, MJ Alam, LY Asad, ME Kabir and T Sikder, 2020. Socio-economic status of buffalo farmers and management practices of buffaloes in selected areas of Jamalpur district. Asian Australas. J. Food Saf. Secur., 4: 49-57.

Hasan T, S Akter, H Biswas, MA Halim, A Alam and K Rafiq, 2016. Economic analysis of small scale dairy buffalo enterprises in Bhola district of Bangladesh. Progress. Agril., 27: 502-510.

Hasnath MA, 1985. Breeding, feeding and management of water buffaloes in Bangladesh. Proceeding of $3^{\text {rd }}$ AAAP Animal Science Congress, Suoel. Vol. I: 70-79.

Hussain I and PR Cheeke, 1996. Evaluation of annual ryegrass straw: corn juice silage with cattle and water buffalo: digestibility in cattle vs. buffalo, and growth performance and subsequent lactational performance of Holstein heifers. Anim. Feed Sci. Tech., 57: 195-202.

Hussain MS, 1990. Performance of indigenous buffaloes in Tangail district. M.S in Animal Science thesis. Bangladesh Agricultural University. Mymensingh.

Ali A, MM Tariq, MA Bajwa, F Abbas, GB Isani, GH Soomro, A Waheed and KU Khan, 2011. A study on performance analysis of Holstein-Friesian cattle herd under semi intensive management at Pishin Dairy Farm Balochistan. ğdır Univ. J. Inst. Sci. \& Tech., 1: 53-57

Kabir ME, MM Monir, MS Islam, MJ Alam and F Dadok, 2020. Existing buffalo husbandry practices at household farming level in selected coastal regions of Bangladesh. Asian J. Med. Biol. Res., 6: 255-264.

Kailash P, R Rathore and M Kumar, 2009. Livelihood improvement of farm women through cattle and buffalo rearing in Jhunjhunu district of Rajasthan. Intl. J. Rural Stud., 16(1).

Khan M, M Saleem, I Rahim, H Khan, A Gohar, S Ahmad, M Salim, Q Ali and Farmanullah, 2014. Assessment of morphometric, productive and reproductive characteristics of Azikheli buffalo in Swat valley in northern Pakistan. Life Sci. J., 11: 1-8.

Saadullah M, 2012. Buffalo production and constants in Bangladesh. J. Anim. Plant Sci., 22: 221-224.

Sarkar S, MM Hossain and MR Amin, 2013. Socio-economic status of buffalo farmers and the management practices of buffaloes in selected areas of Bagerhat District of Bangladesh. Bangladesh Journal of Animal Science, 42: 158-164. 
Siddiki MA, MR Amin, AKMA Kabir, MO Faruqu and ZH Khandaker, 2015. Socio- Economic status of buffalo farmers and the performances of buffaloes At Lalpur Upazila of Natore district in Bangladesh. Bang. J. Anim. Sci., 44: 157-165.

Siddiquee N, MO Faruque, F Islam, MA Mijan and MA Habib, 2010. Morphometric Measurements, reproductive and productive performances of buffalo in Trishal and Companigonj sub-districts of Bangladesh. Intl. J. Biol. Res., 1: 15-21.

Sumaiya U, 2015. Socio-economic status of buffalo farmers and management practices of buffaloes in some selected areas of Moulvibazar district of Bangladesh. MS Thesis. Department of Animal Science. Bangladesh Agricultural University, Mymensingh.

Terramoccia S, S Bartocci, A Amici and F Martillotti, 2000. Protein and protein-free dry matter rumen degradability in buffalo, cattle and sheep fed diets with different forage to concentrate ratios. Live. Prod. Sci., 65: 185-195.

Uddin MK, AA Mintoo, TM Awal, M Kondo and AKMA Kabir, 2016. Characterization of buffalo milk production system in Bangladesh. Bang. J. Anim. Sci., 45: 69-77. 